\title{
THE APPLICATION OF SELECTED MULTIVARIATE STATISTICAL METHODS FOR THE EVALUATION OF TOURISM COMPETITIVENESS OF THE SUDETY COMMUNES
}

The level of tourism destination competitiveness, due to its relatively complex nature, represents a problematic research area. It is difficult to illustrate by means of a single meaningful and credible indicator and thus measures based on a number of variables have to be applied. Therefore, tourism destination competitiveness is very often presented in a theoretical perspective. Empirical applications are encountered much less frequently, especially at a micro level. The purpose of the article is to fill the existing gap by means of linear ordering and the application of cluster analysis methods in order to evaluate the competitiveness of tourism of the Sudety communes.

Keywords: tourism competitiveness, tourism destination, multivariate statistical data analysis, GDM distance

JEL Classifications: C38, C88, L83, R12

DOI: $10.15611 /$ aoe.2018.1.06

\section{INTRODUCTION TO TOURISM DESTINATION COMPETITIVENESS}

In times of market economy such phenomena as competition, competitive advantage and competitiveness are widely discussed and studied by economists. Based on the ABI/Inform database, from 1985 to 2006 more than 4,000 regular papers regarding the concept of competitiveness were published in the reviewed journals in various disciplines presenting different perspectives of the concept (see Hong 2008, pp. 33-34).

The new European Union regional policy, focused on stimulating regional competitiveness as the significant driving force of regional growth, resulted in placing regional competitiveness in the centre of interest within regional studies. It is assumed that regional competitiveness represents the

\footnotetext{
* Department of Marketing and Tourism Management, Faculty of Economics, Management and Tourism, Wrocław University of Economics.

** Department of Econometrics and Computer Science, Faculty of Economics, Management and Tourism, Wrocław University of Economics.
} 
means (a tool) for achieving the overall social development objective, i.e. the increase of regional income and wealth.

The best known definition of Tourism Destination Competitiveness (see e.g. Mazanec, Wöber, Zins 2007) was offered by Ritchie and Crouch 2003, p. 2: "What makes a tourism destination truly competitive is its ability to increase tourism expenditure, to increasingly attract visitors while providing them with satisfying, memorable experiences, and to do so in a profitable way, while enhancing the well-being of destination residents and preserving the natural capital of the destination for future generations".

Regions and tourism destinations can compete in an indirect or direct way (see Markowski 1996, p. 22). Indirect competition should be referred to as the existence and creation of regional environment conditions for companies functioning in it and allowing for gaining competitive advantage within the components outside the control of their operations. It can be presented and measured by means of competitive capacity represented by companies located within its area. On the other hand, direct competition is understood as the rivalry of empowered territorial units which compete for a variety of advantages, access to financial means, attracting external investors, maintaining capital in a region, for the location of state agendas or institutions within their area, and in the most extensive sense - for social and economic development which can guarantee a high quality of life.

All the above-mentioned activities are expected to support the establishment of a regional tourism product and its effective sales in the tourist market. Additionally, it has to be emphasized that tourism-oriented attributes represent a significant component of a tourist region's competitiveness. They are inextricably linked with the space in which they are embedded, cannot be moved and are frequently of a unique nature. They constitute a crucial part of a regional tourist product. All the above factors result in the fact that from the investor's and tourist's perspective it is possible to achieve a tourist revenue. Investors have additional benefits from an investment location in a particular region, e.g. a trend to spend a holiday in a location, its popularity and brand among tourists result in selling the same quality accommodation services at higher prices than in a neighbouring location (Gryszel 2010, pp. 637-653).

Based on the above presented discussion it can be assumed that a competitive tourist region is referred to as an area which is capable of beating the competition from other regions, and from the perspective of tourism, regional competitiveness means the ability to create and establish such a tourist offer (a tourist product) which could differentiate a given 
region from others and as a result attract tourists and extend socio-economic advantages from the development of tourism in this particular area. Therefore, competitiveness is referred to as being different, better or more attractive.

One of the most complete approaches to the problem of competitiveness in tourist regions is the approach presented in the study by Crouch and Ritchie (1999) and later developed in the works by Ritchie and Crouch $(2000,2003)$. It is regarded as the reference point for the majority of models developed after 2000 (Dwyer, Kim 2003; Enright, Newton 2004). The model by J. R. B. Ritchie and G. I. Crouch covers the analysis of over 30 factors of competitiveness divided into five groups (see Figure 1). It is influenced by both the direct and indirect environment. The detailed analysis of the role played by each factor of competitiveness makes their model the most comprehensive theoretical study illustrating practical tips for achieving competitiveness by tourist regions. This model, however, is characterized by a high complexity. Additionally, its existing poor empirical verification stimulates many authors to construct new options capable of reflecting the competitiveness of tourist regions much better in specific cases.

Another model of tourist regions, competitiveness was developed under the guidance of L. Dwyer and C. Kim (Dwyer, Kim 2003; Kim, Dwyer 2003; Dwyer et al. 2004; see Figure 2). Although it was extensively graphically simplified, compared to the one by J.R. B. Ritchie and G. I. Crouch, the difference results from the fact that the authors included only the most important groups of competitiveness factors in it and discussed the particular components covered by these groups only in the form of comments. Therefore it can be noticed that this model is even more extended and complicated than the one suggested by Ritchie and Crouch. In the empirical studies on South Korea's and Australia's competitiveness, the level of each country's competitiveness was measured by as many as 166 indicators (Dwyer et al. 2004), whereas the studies conducted in line with the model by Ritchie and Crouch only 23 factors listed directly in the model graphic presentation were examined (Hudson, Ritchie, Timur 2004). This model was also verified in the study by Gomezelj, Mihalič 2008. The studies performed in accordance with Ritchie and Crouch, as well as Dwyer and Kim's methodology were based on primary data obtained, based on a survey conducted among experts in the field.

It has to be observed that the competitiveness of a tourist region depends on numerous factors. These factors are often independent from the region itself, e.g. a trend to enjoy a particular form of tourism, state economic 


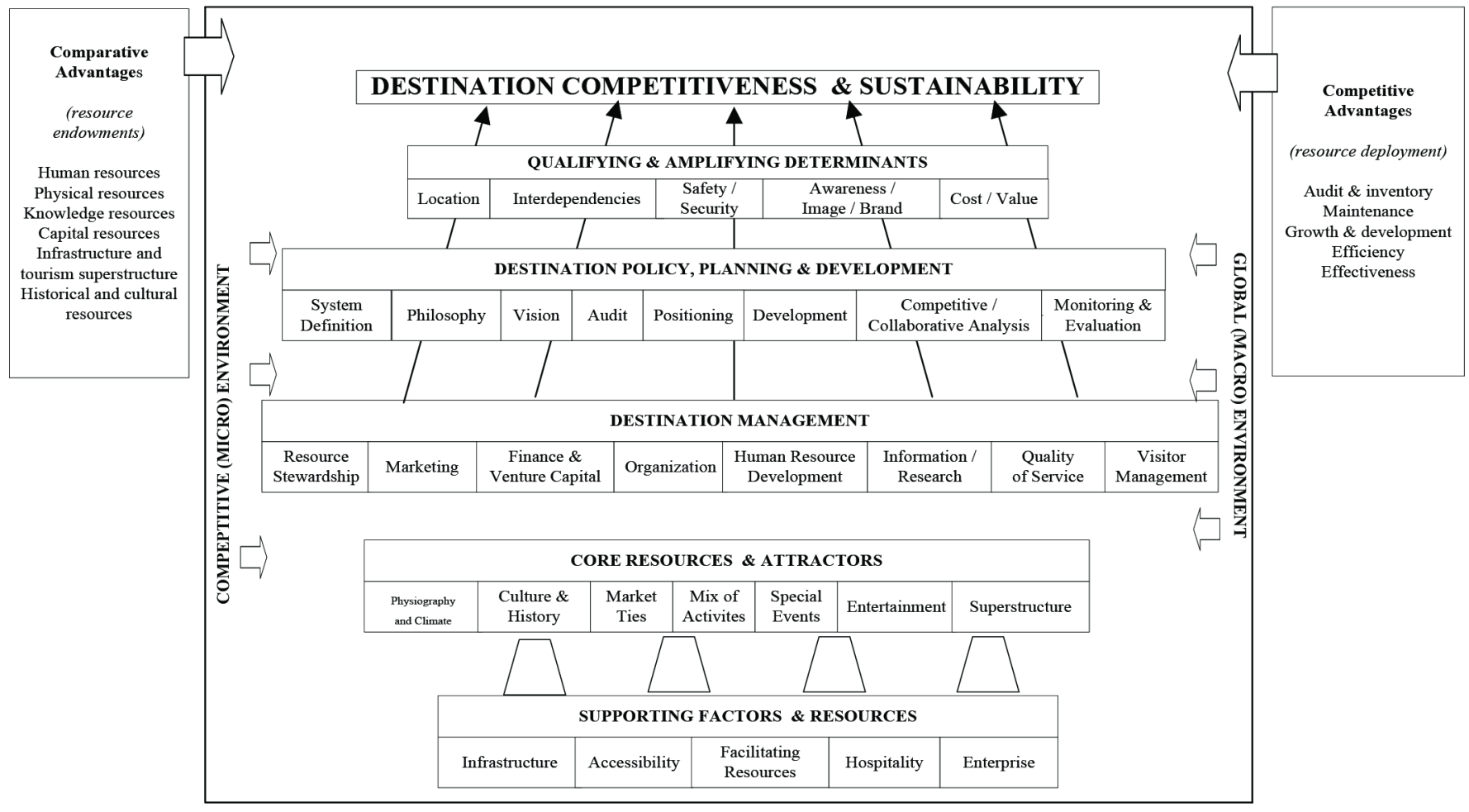

Figure 1. Destination competitiveness and sustainability

Source: Ritchie, Crouch 2000, p. 3. 


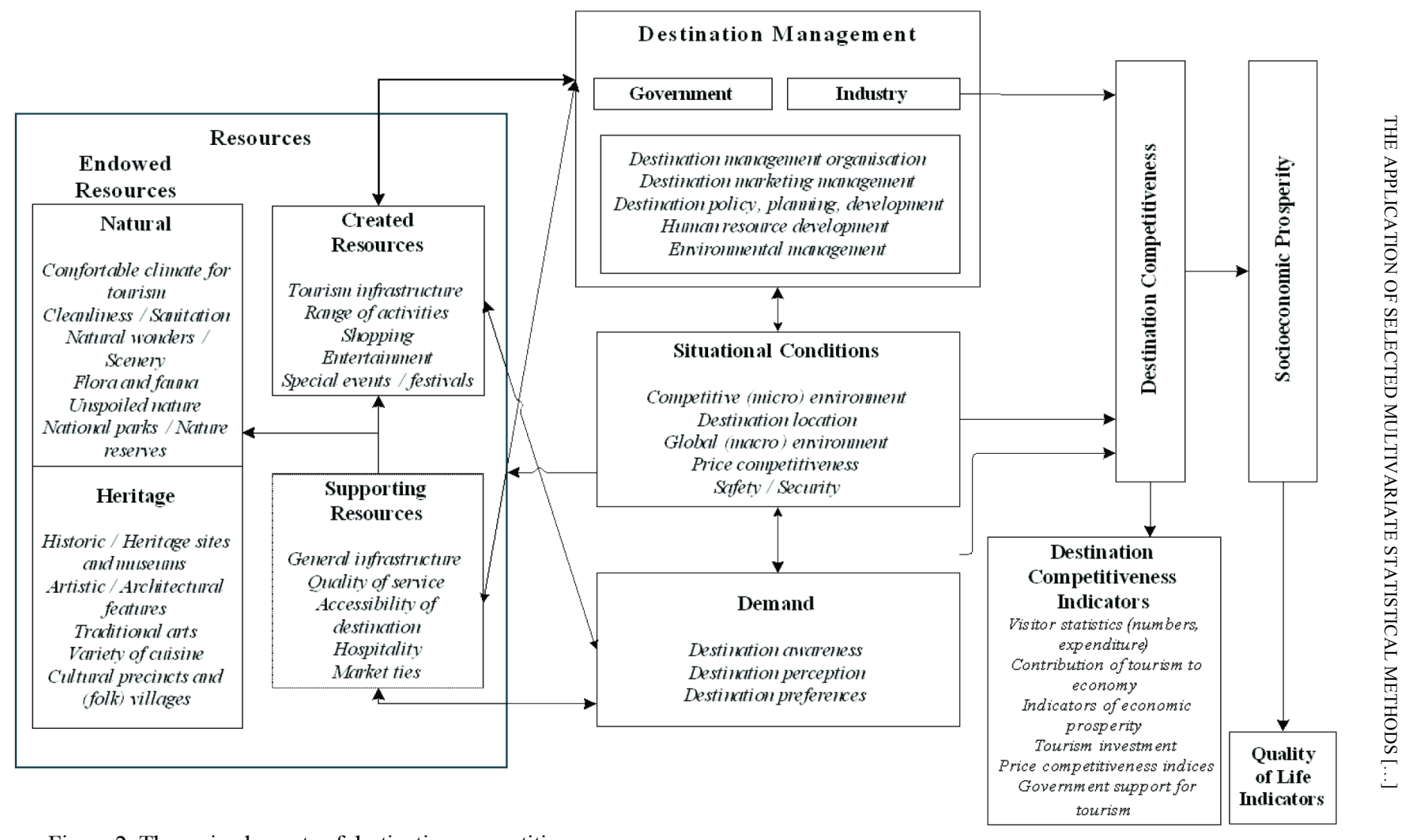

Figure 2. The main elements of destination competitiveness

Source: authors' compilation based on-Dwyer, Kim 2003. 
policy, tourist advantages having an impact on its potential. Many of these factors, however, can be influenced by activities performed within a region, e.g. promotion, the policy followed by regional authorities, appropriate system of the distribution of the tourist product, hospitality, visitor management, tourist management and the cooperation of various entities in creating the regional tourist product.

Ł. Nawrot observed a specific difference in the competitiveness of tourist regions from other regions. The latter have benefits mainly from the location of investments in a region, whereas the final products of investors are distributed to particular sales markets and it is possible to indicate the almost unlimited spatial range of the potential, reachable consumers. A completely different situation is true for tourist enterprises operating in a region. They can expect high profitability only if a high concentration of tourist traffic occurs in a region. Therefore, apart from the rivalry to gain investors, the rivalry to attract tourists is also present in tourist regions (Nawrot 2006, p. 213).

Therefore, one can assume that the competitiveness of tourist regions represents the combination of comparative and competitive advantages. Their theoretical background is embedded in the theory of comparative advantages by D. Ricardo (Porter 1990, p. 20). The comparative advantage of a region results from the ambient factors ingrained in a region which cannot be changed, e.g. natural or anthropogenic values and a climate, or those which can be changed, however, by investing considerable effort and time, e.g. the education of the society (qualifications of workers) and legislation. Competitive advantage refers to the methods for the usage of the existing resources, i.e. comparative advantages. This consists, among others, in using the life cycle of a tourist location or region or implementing innovative solutions (see Ritchie, Crouch 2003, p. 20).

The ability to take effective advantage of tourist regions and to adjust to the changing conditions represents the measure of competitiveness with reference to tourist regions. It is consistent with the approach towards competition which defines it as the capacity for the efficient implementation of goals. In the case of tourist destinations, accomplishing lasting benefits from the development of tourism is the primary objective of all entities operating in a given area (Alejziak 2006, p. 55).

In practice, numerous attempts to assess the competitiveness of tourist regions are being undertaken. The official studies and competitiveness indices most frequently refer to assessing international tourism competetiveness of entire countries as tourist destinations. The Travel and Tourism 
Competitiveness Index (TTCI), published by The World Economic Forum, is the most popular (see Blanke, Chiesa 2013). However, in the case of smaller tourist regions in the geographical meaning, official analyses summarized in reports are performed far less often. The studies conducted by scientists within the framework of research grants or an ongoing academic research, are more frequently encountered. The research conducted by Ch. Schalber and M. Peters (2012) on health oriented tourism in 58 alpine regions can serve as an example. However, they covered the identification of competitiveness factors referring to these regions on health tourism markets, and were not focused on establishing a competitiveness ranking or the comparison of regions with each other.

The results of more extended research conducted using competitiveness measures in the form of indices or linear ordering methods have been, for some time, published mainly in the journal "Tourism Management" (Enright, Newton 2004; Gomezelj, Mihalič 2008; Cracolli and Nijkamp 2009; Zhang et al. 2011; Huang, Peng 2012) and also in: "Journal of Tourism Studies" (Kim, Dwyer 2003), "Journal of Destination Marketing" (Croes, Kubickova 2013), "Journal of Travel Research" (Enright, Newton 2005), "Business and Economics Research" (Serrato et al. 2013). The discussed research covered the tourism competitiveness of cities, regions and countries.

The empirical attempt of assessing tourism competitiveness, with reference to three tourist regions in Poland, i.e. Ustka, Szwajcaria Kaszubska and the south-eastern Kłodzko Valley, was undertaken by $Ł$. Nawrot (Nawrot 2006, pp. 211-232). The study measured the competitiveness of very different tourist destinations. Szwajcaria Kaszubska was analysed as a lake district consisting of six communes. Ustka municipal and rural commune was analysed as a coastal region, whereas the mountainous region of Kłodzko covered six communes located in the south-eastern part of that segment of Sudety. The study was an attempt to diagnose the dynamic competitiveness of tourist regions in the period of 1999-2003. The author analyses each variable separately and does not construct any composite indicator. However, due to their pioneering nature the results of the abovementioned studies should be regarded as worth considering.

The study of tourism competitiveness suggested by the authors and covering the selected Sudety communes is a pioneering one in the Polish market, whereas the suggested research method covering the combined application of cluster analysis and linear ordering method has not been used for this purpose ever before. 


\section{THE ANALYSIS OF DATA REFERRING TO THE SUDETY COMMUNES IN TERMS OF THE LEVEL OF TOURISM COMPETITIVENESS}

169 communes were distinguished in the region of Lower Silesia. The Sudety communes (52 communes) were covered by the study analysing the evaluation of tourism competitiveness. The communes are situated in the geographical area of the Sudety mountains, in the southern part of Lower Silesia. These are also the communes offering the most valuable tourist advantages in which the tourism function plays the dominating role or is of crucial importance among the other economic functions performed by a given commune.

The evaluation of tourism competitiveness, referring to these communes was carried out using 11 metric variables. These variables were selected to characterize the factors of tourist destination's competitiveness defined in Figure 2. Therefore, the conducted analysis covering this assessment is based on secondary data and thus subject to certain limitations. Adequate statistical data were not collected for all the factors presented in Figure 2. The inclusion of some factors requires collecting primary data usually obtained as a result of surveys carried out among experts in the field.

Based on the availability of data referring to communes in the Local Data Bank, the following variables were adopted:

$\mathrm{x} 1$ - beds in hotels per $1 \mathrm{~km}^{2}$ of a commune area,

$\mathrm{x} 2$ - beds in other accommodation facilities per $1 \mathrm{~km}^{2}$ of a commune area,

x3 - number of nights of resident tourists (Poles) per day per 1000 inhabitants of a commune,

$\mathrm{x} 4-$ number of nights of foreign tourists per day per 1000 inhabitants of a commune,

x5 - share of all protected areas (national parks, nature reserves, landscape parks and others) as \% of the commune area,

x6 - communal expenditure for tourism per 1000 inhabitants in PLN,

$\mathrm{x} 7$ - funds obtained from the European Union and from the state budget to finance EU programmes and projects per 1 inhabitant in PLN,

x8 - number of entities of tourist economy per 1000 inhabitants of a commune (natural persons conducting economic activity),

x9 - number of tourist economy entities per 1000 inhabitants of a commune (legal persons and organizational entities without a legal identity),

$\mathrm{x} 10$ - gas pollution emission in tons/year calculated per $1 \mathrm{~km}^{2}$ of a commune area,

$\mathrm{x} 11$ - particulate pollution emission in tons/year calculated per $1 \mathrm{~km}^{2}$ of a commune area. 
Two variables, $\mathrm{x} 10$ and $\mathrm{x} 11$, represent destimulants. The remaining variables are stimulants. The variable $\mathrm{x} 5$ is regarded as a stimulant even though it should be referred to as a nominant. However, it is difficult to define a nominal value for this particular variable. The authors are of the opinion that the share of protected areas in the area of a commune should be nominant specific, since from a certain moment it has a significant impact on upgrading the tourist attractiveness of a region, and thus its competitiveness. After crossing an optimum threshold, the over-excessive size of protected areas in a commune can constitute one of the barriers for making investments in such a commune. Yet the authors did not find the research results confirming this hypothesis. While analysing numerous sustainable development indicators of tourist areas the authors did not come across the desirable values of an indicator for the share of protected areas in the overall area of a commune. Therefore, this can become the subject matter of further research covering this problem.

The statistical data originate from 2012 and come from the Local Data Bank $^{1}$ (LDB), whereas $x 10$ and $x 11$ data originate from 2005, because their publication, with reference to communes, was discontinued.

In order to make the comparison of variables possible the normalization of variables' values was performed with the formula (Walesiak 2014):

$$
z_{i j}=\frac{x_{i j}-\text { med }_{j}}{\sqrt{\sum_{i=1}^{n}\left(x_{i j}-\text { med }_{j}\right)^{2}}},
$$

where: $x_{i j}\left(z_{i j}\right)$ - value (normalized value) of $j$-th variable for $i$-th object, med $_{j}=\operatorname{med}_{i}\left(x_{i j}\right)-$ median for $j$-th variable.

Table 1

The characteristics of variable values distribution after normalization

\begin{tabular}{c|c|c}
\hline Median & Median absolute deviation & Range \\
\hline 0 & $\frac{m a d_{j}}{\sqrt{\sum_{i=1}^{n}\left(x_{i j}-\text { med }_{j}\right)^{2}}}$ & $\frac{r_{j}}{\sqrt{\sum_{i=1}^{n}\left(x_{i j}-\text { med }_{j}\right)^{2}}}$ \\
\hline
\end{tabular}

$\operatorname{mad}_{j}=\operatorname{mad}_{i}\left(x_{i j}\right)-$ median absolute deviation for $j$-th variable.

Source: Walesiak 2014.

\footnotetext{
${ }^{1} \mathrm{http}: / /$ www.stat.gov.pl/bdlen/app/strona.html?p_name=indeks
} 
The purpose of normalization is to adjust the size (magnitude) and the relative weighting of the input variables (see Milligan, Cooper 1988).

Formula (1) is characterized by the properties presented in Table 1 .

The normalization formula (1) is important since it ensures different variability for the normalized variable values (measured by median absolute deviation).

\section{LINEAR ORDERING OF THE SUDETY COMMUNES REGARDING THE LEVEL OF TOURISM COMPETITIVENESS}

The objective of the analysis is to perform the linear ordering of the Sudety communes regarding the level of tourism competitiveness, having applied the general distance measure GDM1 for metric data ${ }^{2}$ (see Walesiak 2011, p. 76; Jajuga, Walesiak, Bąk 2003):

$$
G D M 1_{i}=\frac{1}{2}-\frac{\sum_{j=1}^{m} w_{j}\left(z_{i j}-z_{k j}\right)\left(z_{k j}-z_{i j}\right)+\sum_{j=1}^{m} \sum_{\substack{l=1 \\ l \neq i, k}}^{n} w_{j}\left(z_{i j}-z_{l j}\right)\left(z_{k j}-z_{l j}\right)}{2\left[\sum_{j=1}^{m} \sum_{l=1}^{n} w_{j}\left(z_{i j}-z_{l j}\right)^{2} \sum_{j=1}^{m} \sum_{l=1}^{n} w_{j}\left(z_{k j}-z_{l j}\right)^{2}\right]^{\frac{1}{2}}},
$$

where: $i, k, l=1, \ldots, n$ - the number of the object,

$j=1, \ldots, m-$ the number of the variable,

$z_{i j}\left(z_{k j}, z_{l j}\right)-i$-th $(k$-th, $l$-th) normalized observation on $j$-th variable,

$w_{j}$ - weight of $j$-th variable: $w_{j} \in[0 ; 1]$ and $\sum_{j=1}^{m} w_{j}=1$ or $w_{j} \in[0 ; m]$ and $\sum_{j=1}^{m} w_{j}=m$.

The properties of the general distance measure GDM1 are as follows:

- it can be applied when the variables are measured on an interval or ratio scale,

- it takes values from $[0 ; 1]$ interval. Value 0 indicates that for the compared objects $i, k$ between the corresponding observations of variables, only "equal to" relations take place,

- it satisfies the conditions: non-negative, reflexive, and symmetric (for all $i, k=1, \ldots, n)$,

\footnotetext{
${ }^{2}$ For the variables measured on ordinal scale GDM2 distance is applied (see Walesiak 1999).
} 
- the empirical analysis proves that distance $G D M 1$ sometimes does not satisfy the triangle inequality,

- it needs at least one pair of non-identical objects in order to avoid zero in the denominator,

- $G D M 1=1$ if a set of objects contains two objects only,

- the transformation of data by any linear function does not change the value of distance.

Table 2

The results of linear ordering of the Sudety communes referring to the level of tourist competitiveness

\begin{tabular}{|c|c|c|c|c|c|c|c|}
\hline No. & Commune & $G D M 1_{i}$ & Class & No. & Commune & $G D M 1_{i}$ & Class \\
\hline 1 & 2 & 3 & 4 & 5 & 6 & 7 & 8 \\
\hline 1 & Model commune & 0.0000 & \multirow{11}{*}{ I } & 28 & Czarny Bór (2) & 0.5176 & \multirow{26}{*}{ III } \\
\hline 2 & Karpacz (1) & 0.0303 & & 29 & \begin{tabular}{|l|} 
Pieszyce (1) \\
\end{tabular} & 0.5217 & \\
\hline 3 & Świeradów-Zdrój (1) & 0.1541 & & 30 & Marciszów (2) & 0.5226 & \\
\hline 4 & Szklarska Poręba (1) & 0.2292 & & 31 & Piechowice (1) & 0.5245 & \\
\hline 5 & Duszniki-Zdrój (1) & 0.2560 & & 32 & Boguszów-Gorce (1) & 0.5307 & \\
\hline 6 & Polanica-Zdrój (1) & 0.2678 & & 33 & Głuszyca (3) & 0.5308 & \\
\hline 7 & Szczawno-Zdrój (1) & 0.2832 & & 34 & Stare Bogaczowice (2) & 0.5311 & \\
\hline 8 & Kudowa Zdrój (1) & 0.3078 & & 35 & Radków (3) & 0.5332 & \\
\hline 9 & Jelenia Góra (1) & 0.3139 & & 36 & Jeżów Sudecki (2) & 0.5357 & \\
\hline 10 & Jedlina-Zdrój (1) & 0.3606 & & 37 & Bielawa (1) & 0.5385 & \\
\hline 11 & Lądek-Zdrój (3) & 0.3710 & & 38 & Stara Kamienica (2) & 0.5412 & \\
\hline 12 & Stronie Śląskie (3) & 0.3834 & \multirow{15}{*}{ II } & 39 & Wałbrzych (1) & 0.5428 & \\
\hline 13 & Podgórzyn (2) & 0.4326 & & 40 & Nowa Ruda (2) & 0.5439 & \\
\hline 14 & Mysłakowice (2) & 0.4572 & & 41 & Kamienna Góra (1) & 0.5451 & \\
\hline 15 & Walim (2) & 0.4632 & & 42 & Kłodzko (1) & 0.5458 & \\
\hline 16 & Bardo (3) & 0.4706 & & 43 & Ciepłowody (2) & 0.5496 & \\
\hline 17 & Kamienna Góra (2) & 0.4743 & & 44 & Lubawka (3) & 0.5541 & \\
\hline 18 & Mieroszów (3) & 0.4879 & & 45 & Dzierżoniów (1) & 0.5568 & \\
\hline 19 & Janowice Wielkie (2) & 0.4938 & & 46 & Wojcieszów (1) & 0.5599 & \\
\hline 20 & Szczytna (3) & 0.4988 & & 47 & Nowa Ruda (1) & 0.5614 & \\
\hline 21 & Wleń (3) & 0.4991 & & 48 & Dzierżoniów (2) & 0.5683 & \\
\hline 22 & Złoty Stok (3) & 0.5034 & & 49 & Kłodzko (2) & 0.5695 & \\
\hline 23 & Kowary (1) & 0.5041 & & 50 & Ząbkowice Śląskie (3) & 0.5721 & \\
\hline 24 & Bystrzyca Kłodzka (3) & 0.5068 & & 51 & Lubań (1) & 0.5722 & \\
\hline 25 & Lewin Kłodzki (2) & 0.5140 & & 52 & Kamieniec Ząbkowicki (2) & 0.5739 & \\
\hline 26 & Stoszowice (2) & 0.5152 & & 53 & Piława Górna (1) & 0.5900 & \\
\hline
\end{tabular}

the first quartile $=0.4572375 ;$ median $=0.517147$; the third quartile $=0.5439450$; mad $=0.05473955, G D M 1-$ GDM1 distance of $i$-th object (commune) from the model (pattern) object, (1) - municipal commune, (2) - rural commune, (3) - municipal-rural commune.

Source: own calculations using clusterSim package of $\mathrm{R}$ program. 
The function pattern.GDM1 (GDM1 distance with equal weights) of clusterSim package of R program was applied (Walesiak and Dudek [2014]) where the ideal point co-ordinates consist of the best variables' values (maximum for stimulants and minimum for destimulants).

The results of linear ordering of the Sudety communes referring to the level of tourism competitiveness are presented in Table 2 and Figure 3.

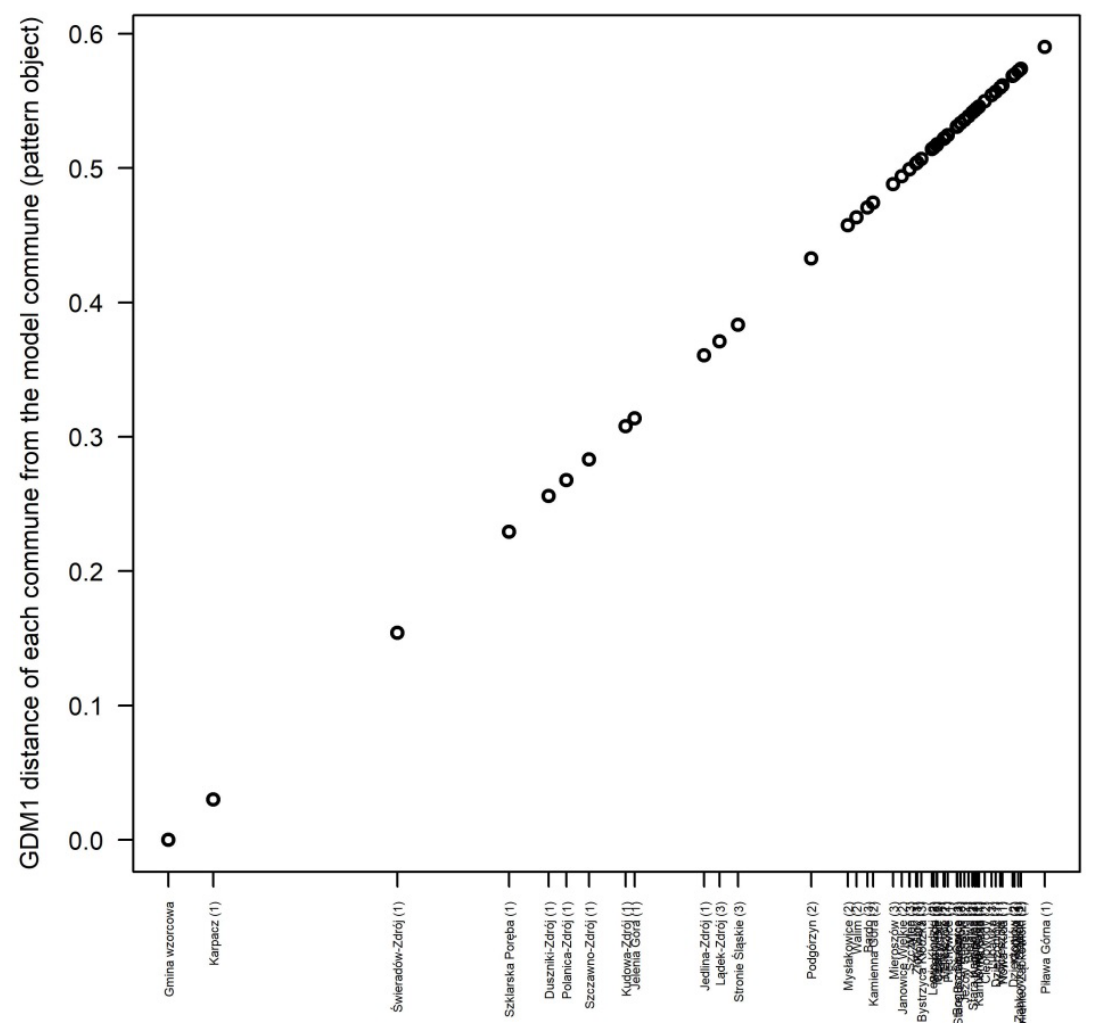

Figure 3. Graphic presentation of the Sudety communes ordering regarding the level of tourism competitiveness in 2012, from the best to the worst, in accordance with GDM1 distances

Source: own elaboration using clusterSim package of $\mathrm{R}$ program.

The typological classes in Table 2 were defined in accordance with the positional approach (Lira, Wagner, Wysocki 2000, p. 93):

Class I: $G D M 1_{i}<\operatorname{med}-2.5 \mathrm{mad}$

Class II: $\operatorname{med}-2.5 \mathrm{mad} \leq G D M 1_{i}<$ med
Class III:

$$
\text { med } \leq G D M 1_{i}<\text { med }+2.5 \text { mad }
$$

Class IV: $G D M 1_{i} \geq$ med $+2.5 \mathrm{mad}$ 
The first typological class, including the model commune, covers 10 communes presenting the highest level of tourism competitiveness. The second typological class covers 16 communes featuring an average level of tourism competitiveness, while the third class includes 26 communes with low levels of tourism competitiveness. No commune was classified in class four characterized by a very low level of tourism competitiveness.

Figure $4 \mathrm{a}$ presents the box plot for 11 variables after normalization and Figure $4 \mathrm{~b}$ for the aggregated variable referring to GDM1 distance of each commune from the model commune (pattern object).

a)

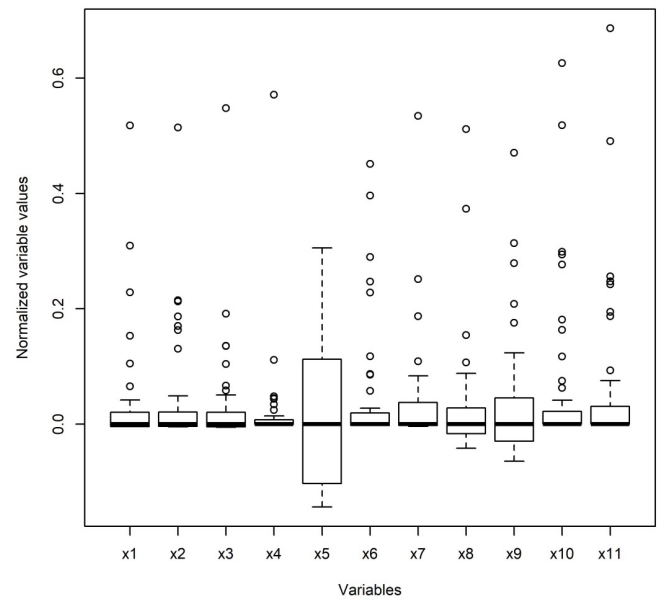

b)

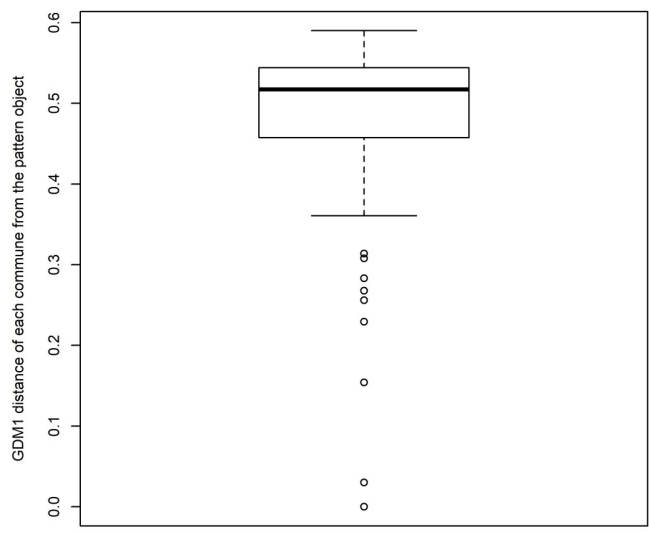

Aggregated variable

Figure 4. Box plot for variables after normalization (a) and for the aggregated variable (b) Source: own elaboration using $\mathrm{R}$ program. 
The horizontal line in a box presents the second quartile (median value). The bottom (top) line of the box presents the first (the third) quartile. The values presented in the picture, which are higher (lower) than the sum (difference) of the third quartile and three quartile deviations are considered outliers (marked by a circle in the picture). The position of the median line in the box illustrates the distribution skewness for the particular variables.

The distribution of ten variables is asymmetric and characterized by outliers (the distribution is symmetrical and without outliers for $\mathrm{x} 5$ variable only). The distribution of aggregated variable (GDM1 distance values of communes from the pattern object) is asymmetric and covers nine outliers. These are the communes presenting the highest level of tourism competitiveness: model commune, Karpacz (1), Świeradów-Zdrój (1), Szklarska Poręba (1), Duszniki-Zdrój (1), Polanica-Zdrój (1), SzczawnoZdrój (1), Kudowa Zdrój (1), Jelenia Góra (1).

\section{CLASSIFICATION OF THE SUDETY COMMUNES REGARDING THE LEVEL OF TOURISM COMPETITIVENESS}

The objective of the study is to distinguish, using cluster analysis, the relatively homogenous clusters of the Sudety communes presenting similar levels of tourism competitiveness. While carrying out the cluster analysis in $\mathrm{R}$ program the following methodology was adopted:

- in order to check the metric data in terms of compatibility the normalization of variable values was applied in line with formula (1) data. Normalization of clusterSim package was applied (Walesiak and Dudek 2014),

- to specify the distance matrix GDM1 distance measure was applied for metric data (formula (2) with equal weights),

- to classify the set of objects into relatively homogenous clusters $k$ medoids the clustering method PAM was used (Kaufman and Rousseeuw 1990),

- to define the number of clusters into which the analysed set of communes should be classified, it was adopted that the silhouette index of the evaluation of the classification results' quality (see Kaufman and Rousseeuw 1990, pp. 83-88; Walesiak 2011, p. 61) will not be less than 0.60 and the obtained division of the communes' set will be stable. The analysis of replication using replication.Mod of clusterSim package (Walesiak and Dudek 2014) was applied for the stability evaluation of the obtained set division into clusters. These conditions were met through the 
division of the communes' set into four clusters. The value of silhouette index equal 0.6255 was calculated. This means that a reasonable cluster structure was obtained (see Kaufman and Rousseeuw 1990, p. 88; Walesiak 2009, p. 420).

Table 3 presents the division results of the analysed set of communes featuring similar tourist competitiveness level into four clusters and the characteristics of the particular clusters.

\section{Table 3}

The results of the analysed set of communes division into four clusters presenting a similar level of tourism competitiveness and the characteristics of particular clusters

\begin{tabular}{|c|c|c|c|}
\hline $\begin{array}{c}\text { Cluster } I \\
(6 \text { communes }+ \\
\text { model commune) }\end{array}$ & $\begin{array}{c}\text { Cluster II } \\
\text { (34 communes) }\end{array}$ & $\begin{array}{c}\text { Cluster III } \\
\text { (7 communes) }\end{array}$ & $\begin{array}{c}\text { Cluster IV } \\
\text { (5 communes) }\end{array}$ \\
\hline $\begin{array}{l}\text { Karpacz (1) } \\
\text { Szklarska Poręba (1) } \\
\text { Świeradów-Zdrój (1) } \\
\text { Kudowa-Zdrój (1) } \\
\text { Polanica-Zdrój (1) } \\
\text { Szczawno-Zdrój (1) } \\
\text { Model commune }\end{array}$ & $\begin{array}{l}\text { Kowary (1), Piechowice (1), } \\
\text { Janowice Wielkie (2), Jeżów } \\
\text { Sudecki (2), Mysłakowice (2), } \\
\text { Podgórzyn (2), Stara Kamienica (2), } \\
\text { Kamienna Góra (2), Lubawka (3), } \\
\text { Marciszów (2), Wleń (3), } \\
\text { Wojcieszów (1), Pieszyce (1), } \\
\text { Piława Górna (1), Dzierżoniów (2), } \\
\text { Bystrzyca Kłodzka (3), Kłodzko (2), } \\
\text { Lewin Kłodzki (2), Międzylesie (3), } \\
\text { Nowa Ruda (2), Radków (3), } \\
\text { Szczytna (3), Boguszów-Gorce (1), } \\
\text { Czarny Bór (2), Głuszyca (3), } \\
\text { Mieroszów (3), Stare Bogaczowice } \\
\text { (2), Walim (2), Bardo (3), } \\
\text { Ciepłowody (2), Kamieniec } \\
\text { Ząbkowicki (2), Stoszowice (2), } \\
\text { Ząbkowice Śląskie (3), Złoty Stok (3) }\end{array}$ & $\begin{array}{l}\text { Kamienna Góra (1) } \\
\text { Lubań (1) } \\
\text { Bielawa (1) } \\
\text { Dzierżoniów (1) } \\
\text { Kłodzko (1) } \\
\text { Nowa Ruda (1) } \\
\text { Wałbrzych (1) }\end{array}$ & $\begin{array}{l}\text { Jelenia Góra (1) } \\
\text { Duszniki-Zdrój (1) } \\
\text { Lądek-Zdrój (3) } \\
\text { Stronie Śląskie (3) } \\
\text { Jedlina-Zdrój (1) }\end{array}$ \\
\hline \multicolumn{4}{|c|}{ A commune occupying central position (medoid) in the cluster } \\
\hline Polanica-Zdrój (1) & Nowa Ruda (2) & Dzierżoniów (1) & Jedlina-Zdrój (1) \\
\hline \multicolumn{4}{|c|}{ Average distance of communes in a cluster from an object occupying the central position } \\
\hline 0.1197 & 0.0235 & 0.0298 & 0.0537 \\
\hline \multicolumn{4}{|c|}{ The largest distance between communes in a cluster } \\
\hline 0.2552 & 0.0760 & 0.0947 & 0.1596 \\
\hline
\end{tabular}

(1) - municipal commune, (2) - rural commune, (3) - municipal-rural commune.

Source: own elaboration using R program.

By applying the replication analysis, the stability level was evaluated regarding the conducted classification of the set of objects. The level of the adjusted Rand index (see Hubert, Arabie 1985) reflects the stability of the performed classification covering the set of objects. Measure values are included in $[-\infty ; 1]$ range. The obtained value of the adjusted Rand index 
(0.6244) confirms the stable division of 53 objects (52 communes and the model commune) into four clusters. Therefore, separating four clusters of communes, characterized by a similar tourist competitiveness level in the analysed set is by all means justified.

In order to facilitate the interpretation of the obtained classification results the cluster centres were specified (arithmetic means of variable values describing communes in a given cluster):

[1] Arithmetic means

\begin{tabular}{|c|c|c|c|c|c|}
\hline$[, 1]$ & {$[, 2]$} & {$[, 3]$} & {$[, 4]$} & {$[$, } & \\
\hline$[1,] \mathbf{6 0 . 2 6 8 5 7 1}$ & 71.918571 & 189.4171 & 40.1985714 & 34.550000 & 137883.529 \\
\hline$[2] 1.012647$, & 1.681471 & 5.4150 & 0.4052941 & 26.276765 & 10401.280 \\
\hline$[3,] \overline{4.032857}$ & $\underline{1.530000}$ & $\underline{1.0500}$ & $\underline{0.2357143}$ & $\underline{8.987143}$ & $\underline{6170.277}$ \\
\hline$[4] 6.358000$, & $\overline{17.330000}$ & $\overline{32.0860}$ & 2.5780000 & $\overline{57.314000}$ & $\overline{256947.714}$ \\
\hline$[, 7]$ & {$[, 8]$} & [,9] & {$[, 10]$} & {$[, 11]$} & \\
\hline$[1,] \mathbf{1 9 7 . 0 9 0 0 0}$ & 47.712857 & 10.124286 & 73.41571 & 0.07142857 & \\
\hline$[2] 25.84765$, & $\underline{9.867941}$ & 2.408824 & 29.05412 & 0.10147059 & \\
\hline$[3] 18.90571$, & 10.207143 & 2.774286 & 1742.15000 & 3.11285714 & \\
\hline$[4] 61.13000$, & 15.788000 & 4.362000 & 203.99600 & 0.18400000 & \\
\hline
\end{tabular}

The underlined numbers refer to the least favourable values (minimum for a stimulant and maximum for a destimulant), whereas the numbers in bold refer to the most favourable values for particular variables in clusters (maximum in the case of a stimulant and minimum for a destimulant).

\section{CONCLUSIONS}

As a result of the applied research procedure the diagnosis of static competitiveness was performed and covered the selected Sudety tourist communes in 2012. The linear ordering (see the results presented in Table 2) and cluster analysis (see the results presented in Table 3) were conducted of the Sudety communes referring to the level of tourism competitiveness using the GDM1 distance measure appropriate for metric data.

Four clusters of communes featuring similar tourism competitiveness were distinguished (see cluster analysis results presented in Table 3).

The first cluster covers six communes and a model commune. These communes are characterized by the highest level of tourism competitiveness (see the linear ordering results presented in Table 2). The most competitive tourist commune of the Sudety is Karpacz, followed by Szklarska Poręba. This class also includes four spa communes, therefore one can assume that the existence of the spa advantage in the commune area determines such activities of local authorities and businesses which influence the high 
competitive position of this type of territorial self-government entities. Due to statutory restrictions in running other types of economic activities, such communes are designated for the development of a tourist function. Therefore, they have to take care of their tourism competitiveness since the development of tourism remains the basis of these communes residents' living standards and their overall quality of life. Tourism plays the polarizing role in a commune, i.e. determines the development of a commune, and is of dominating importance. We refer to such locations and regions as the ones featuring a significantly developed tourist function.

The second cluster, characterized by average and low tourism competitiveness level (see the linear ordering results presented in Table 2), covers 34 communes in which tourism stimulates development and represents one of the components facilitating the area's development in an indirect way. These locations and regions are referred to as the ones presenting a diversified functional structure which, by influencing their tourism competitiveness, have an impact on the entire regional competitiveness.

The third cluster covers seven communes characterized by the low level of tourism competitiveness. It includes the largest towns of the Sudety constituting municipal communes (except Jelenia Góra). Due to the number of inhabitants in these towns and the need to provide jobs in a diversified economy, the tourist function in such communes is of neutral nature and does not affect the area development to a great extent, but rather plays a supplementary role. In this case the respective regions and locations feature a highly diversified functional structure which results in a lower level of tourism competitiveness.

The fourth cluster covers five communes characterized by a very specific nature. It includes three typical spa communes as well as Jelenia Góra and Stronie Śląskie. These communes feature high level of tourism competetiveness (positions 5, 9, 10, 11 and 12 in Table 3), but their characteristic attributes distinguish them from the analysed group. Jelenia Góra has about 80,000 inhabitants and is a town of a multi-functional nature. In 1976, its borders were enlarged by the resort of Cieplice and also the typically tourist locations of Sobieszów and Jagniątków; it also has a well-developed industrial function. Duszniki-Zdrój is situated between two large spa resorts characterized by a very high competitive position, which resulted in the industrial function having been introduced in the city. Jedlina-Zdrój represents, on the other hand, one of the smaller spa resorts in the region since it offers only 180 spa accommodation places. It is located in the 
Wałbrzych agglomeration and is spreading towards the industrial city of Wałbrzych. Lądek-Zdrój and Stronie Śląskie are characterized by the most peripheral location and poor transport accessibility. Stronie Śląskie is a commune presenting valuable tourist attributes, however, since it concentrated on mining in the past (mainly uranium ore), currently it is also developing an industrial function apart from the tourist one.

\section{REFERENCES}

Alejziak, W., Wielkie wydarzenia sportowe jako czynnik walki konkurencyjnej na globalnym rynku turystycznym [Major Sporting Events as the Competition Factor at the Global Tourist Market], [in:] Gołembski, G. (ed.), Turystyka jako czynnik wzrostu konkurencyjności regionnów w dobie globalizacji [Tourism as the Factor of Increasing Competitiveness in Times of Globalization]. Wydawnictwo Akademii Ekonomicznej w Poznaniu, Poznań, 2006.

Blanke, J., Chiesa, T. (eds.), The Travel \& Tourism Competitiveness Report 2013, World Economic Forum, Geneva, 2013.

Cracolici, M. F., Nijkamp, P., The Attractiveness and Competitiveness of Tourist Destinations: A Study of Southern Italian Regions, "Tourism Management", Vol. 30, Issue 3, pp. 336-344, 2009.

Croes, R., Kubickova, M., From Potential to Ability to Compete: Towards a Performancebased Tourism Competitiveness Index, "Journal of Destination Marketing \& Management”, Vol. 2, Issue 3, pp. 146-154, 2013.

Crouch, G. I., Ritchie, J. R. B., Tourism, Competitiveness, and Societal Prosperity, "Journal of Business Research", Vol. 44, Issue 3, pp. 137-152, 1999.

Dwyer, L., Kim, C., Destination Competitiveness: Determinants and Indicators, "Current Issues in Tourism", Vol. 6, No 5, pp. 369-414, 2003.

Dwyer, L., Mellor, R., Livaic, Z., Edwards, D., Kim, C., Attributes of Destination Competitiveness: A Factor Analysis, "Tourism Analysis", Vol. 9, No 1-2, pp. 91-101, 2004.

Enright, M. J., Newton, J., Tourism Destination Competitiveness: A Quantitative Approach, “Tourism Management”, Vol. 25, Issue 6, pp. 777-788, 2004.

Enright, M. J., Newton, J., Determinants of Tourism Destination Competitiveness in Asia Pacific: Comprehensiveness and Universality, "Journal of Travel Research", Vol. 43, May, pp. 339$-350,2005$.

Gomezelj, D. O., Mihalič, T., Destination Competitiveness - Applying Different Model, the Case of Slovenia, “Tourism Management”, Vol. 29, Issue 2, pp. 294-307, 2008.

Gryszel, P., Destination Management Company a ksztaltowanie konkurencyjności obszaru turystycznego [Destination Management Company vs. Influencing Competitiveness of a Tourist Destination], [in:] Sala, J. (ed.), Konkurencyjność miast i regionów na globalnym rynku turystycznym [Competitiveness of Towns and Regions in the Global Tourist Market]. PWE, Warszawa, 2010.

Hong, W., Competitiveness in the Tourism Sector. A Comprehensive Approach from Economic and Management Points. Physica-Verlag, Heidelberg, 2008. 
Huang, J., Peng, K., Fuzzy Rasch Model in TOPSIS: A New Approach for Generating Fuzzy Numbers to Assess the Competitiveness of the Tourism Industries in Asian countries, “Tourism Management”, Vol. 33, Issue 2, pp. 456-465, 2012.

Hubert, L., Arabie, P., Comparing Partitions, “Journal of Classification”, No. 1, pp. 193-218, 1985.

Hudson, S., Ritchie, J. R. B., Timur, S., Measuring Destination Competitiveness: An Empirical Study of Canadian Ski Resorts, "Tourism and Hospitality Planning \& Development", Vol. 1, No. 1, pp. 79-94, 2004.

Jajuga, K., Walesiak, M., Bąk, A., On the General Distance Measure, [in:] M. Schwaiger, M., Opitz, O. (eds.), Exploratory Data Analysis in Empirical Research, pp. 104-109. SpringerVerlag, Berlin, Heidelberg, 2003.

Kaufman, L., Rousseeuw, P. J., Finding Groups in Data: An Introduction to Cluster Analysis. Wiley, New York, 1990.

Kim, C., Dwyer, L., Destination Competitiveness and Bilateral Tourism Flows between Australia and Korea, "The Journal of Tourism Studies", Vol. 14, No. 2, pp. 55-67, 2003.

Lira, J., Wagner, W., Wysocki, F., Mediana w zagadnieniach porzadkowania liniowego obiektów wielocechowych [Median in Linear Ordering of Multivariate Objects] [in:] Paradysz, J. (ed.), Statystyka regionalna w stużbie samorzadu lokalnego i biznesu [Regional Statistics for Local Self-Government and Business], pp. 87-99. Internetowa Oficyna Wydawnicza, Centrum Statystyki Regionalnej, Akademia Ekonomiczna w Poznaniu, Poznań, 2002.

Markowski, T., Od konkurencji zasobów do konkurencji regionów [From Competition of Resources to Competition of Regions], „Samorząd Terytorialny” No. 12, pp. 12-26, 1996.

Mazanec, J. A., Wöber, K., Zins A. H., Tourism Destination Competitiveness: From Definition to Explanation?, "Journal of Travel Research", Vol. 46, No. 1, pp. 86-95, 2007.

Milligan G. W., Cooper M. C., A Study of Standardization of Variables in Cluster Analysis, "Journal of Classification", No. 2, pp. 181-204, 1988.

Nawrot, Ł., Bezpośrednia konkurencyjność regionu turystycznego - istota i możliwość pomiaru [Direct Competitiveness of a Tourist Region - The Essence and Measurement Possibility] [in:] Gołembski, G. (ed.) Turystyka jako czynnik wzrostu konkurencyjności regionów $w$ dobie globalizacji [Tourism as the Factor of Increasing Competitiveness in Times of Globalization]. Wydawnictwo Akademii Ekonomicznej w Poznaniu, Poznań, 2006.

Porter, M. E., Competitive Advantage of Nations. Free Press, New York, 1990.

R Core Team, R: A Language and Environment for Statistical Computing, R Foundation for Statistical Computing, Vienna, URL http://www.R-project.org, 2014.

Ritchie, J. R. B., Crouch, G. I., The Competitive Destination: A Sustainability Perspective, "Tourism Management", Vol. 21, pp. 1-7, 2000.

Ritchie, J. R. B., Crouch, G. I., The Competitive Destination. A Sustainable Tourism Perspective, CABI, Wallingford, 2003.

Schalber, C., Peters, M., Determinants of Health Tourism Competitiveness: An Alpine Case Study, “Tourism Review”, Vol. 60, No. 3, pp. 307-323, 2012.

Serrato, M., Valenzuela, K., Rayas, V., Improving Tourism Competitiveness: The Case of Mexico, "Business and Economic Research", Vol. 3, No. 1, pp. 388-405, 2013.

Walesiak, M., Distance Measure for Ordinal Data, "Argumenta Oeconomica”, No. 2 (8), pp. 167-173, 1999. 
Walesiak, M., Analiza skupień [Cluster analysis] [in:] Walesiak, M., Gatnar, E. (eds.), Statystyczna analiza danych $z$ wykorzystaniem programu $R$ [Statistical Data Analysis with R Program]. Wydawnictwo Naukowe PWN, Warszawa, pp. 407-433, 2009.

Walesiak, M., Uogólniona miara odległości GDM w statystycznej analizie wielowymiarowej $z$ wykorzystaniem programu $R$ [General Distance Measure GDM in Multivariate Statistical Analysis Applying R Program]. Wydawnictwo Uniwersytetu Ekonomicznego we Wrocławiu, Wrocław, 2011.

Walesiak, M., Przeglą formul normalizacji wartości zmiennych oraz ich własności w statystycznej analizie wielowymiarowej [The Review of Normalization Formulas of Variable Values and Their Properties in Multivariate Statistical Analysis], "Przegląd Statystyczny", Vol. 61, No. 4, pp. 363-372, 2014.

Walesiak, M., Dudek, A., clusterSim package, URL http://www.R-project.org, 2014.

Zhang, H., Gu, C., Gu, L., Zhang, Y., The Evaluation of Tourism Destination Competitiveness by TOPSIS \& Information Entropy - A Case in the Yangtze River Delta of China, "Tourism Management", Vol. 32, Issue 2, pp. 443-451, 2011.

Received: June 2014 